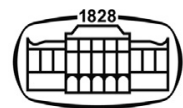

AKADÉMIAI KIADÓ

Acta Chromatographica

33 (2021) 3, 253-260

DOl:

$10.1556 / 1326.2020 .00811$

(c) 2020 The Authors

ORIGINAL RESEARCH PAPER

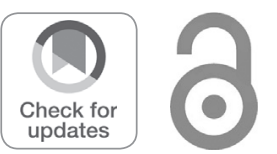

\section{Determination of ligustrazine in rat serum by polymer monolithic micro-extraction combined with ultra high performance liquid chromatography-tandem mass spectrometry}

\author{
DANLING SUN ${ }^{1}$, XITIAN PENG ${ }^{2}$, MAOMIN PENG ${ }^{2}$, \\ XIAN ZHANG ${ }^{2}$, HONG XIA $^{2}$, ZHIMIN XU ${ }^{3}$ and \\ $\mathrm{XIZHOU} \mathrm{HU} \mathrm{H}^{2,3^{*}}$ \\ ${ }^{1}$ College of Laboratory Medicine, Hubei University of Chinese Medicine, Wuhan, 430065, China \\ ${ }^{2}$ Institute of Quality Standards and Testing Technology for Agro-Products, Hubei Academy of \\ Agricultural Sciences/Hubei Key Laboratory of Nutritional Quality and Safety of Agro-products, \\ Wuhan, 430064, China \\ ${ }^{3}$ School of Nutrition and Food Sciences, Louisiana State University, Baton Rouge, LA, 70803, USA
}

Received: June 24, 2020 - Accepted: August 4, 2020

Published online: September 17, 2020

\begin{abstract}
This study focused on developing an effective and environmentally friendly method to measure ligustrazine in rat serum by using polymer monolith micro-extraction (PMME) technique. A poly (methacrylic acid-ethylene glycol dimethacrylate) material was used to extract ligustrazine through hydrophobic and ion-exchange interaction. Qualitative and quantitative analysis was performed by a liquid chromatography and tandem mass spectrometry. After optimization of several PMME conditions, the developed method exhibited excellent extraction performance to the ligustrazine. Good linearity was acquired ranging from 10 to $2,000 \mathrm{ng} \mathrm{mL}^{-1}$, and the limit of detection of the proposed method was $0.14 \mathrm{ng} \mathrm{mL}^{-1}$. The recoveries measured by spiking three different concentrations in rat serum ranged from 82.6 to $95.3 \%$, and excellent precision was found with relative standard deviations (RSDs) less than $8.3 \%$ for intra-day and $9.7 \%$ for inter-day, respectively. At last, the applicability of the method was further confirmed through continuous monitoring of ligustrazine in rat serum after dosing of ligustrazine tablets to rats.
\end{abstract}

\section{KEYWORDS}

polymer monolith microextraction (PMME), determination, ligustrazine, rat serum

\section{INTRODUCTION}

Rhizoma Ligusticum chuanxiong (Chuanxiong) are becoming increasingly popular due to their low toxicity and good therapeutic performance in treatment of many human diseases [1, 2]. Chuanxiong consists of a main active ingredient called ligustrazine, which can inhibit platelet aggregation in vitro and lowers blood pressure by vasodilation. It has been proved that this herb can treat a variety of cardiovascular disorders, including myocardial and cerebral infarction [2-7]. However, rapid degradation and low bioavailability of ligustrazine limit its treatment effect. Furthermore, routine determination of ligustrazine involves timeconsuming and tedious procedures [7,8]. Thus, a rapid method to measure ligustrazine, especially in biological samples, such as serum is highly desired.

Various methods, such as liquid chromatography with ultraviolet detector [7, 9, 10], gas chromatography-mass spectrometry [11], electrochemical methods [12, 13] were reported to determinate ligustrazine in different biological samples. Recently, qualitative and quantitative 
analysis for ligustrazine using mass spectrometry technique has become popular because of its highly selective and sensitive detection for many different types of samples [1417]. Duo to complex biological sample matrices, those interferences co-extracted with target analytes should be removed prior to subsequent instrumental analysis. Several traditional purification methods as LLE or SPE procedures have been applied to extract ligustrazine from biological matrices $[4,9,10,12,13,15,16,18,19]$. However, large volume of sample and solvent or time-consuming extraction procedures were usually required for them. Polymer monolith micro-extraction (PMME) has gained much attention in sample preparation for various applications [20-22]. As a polymer extraction material, poly (methacrylic acid-ethylene glycol dimethacrylate) [poly (MAA-EGDMA)] could provide good biocompatibility for much biological samples, which possessed good permeability to make extraction faster and performed high-throughput analysis. Moreover, good stability in a wide range of $\mathrm{pH}$ was suitable for processing biological samples [22-24].

In this study, PMME using a poly (MAA-EGDMA) monolithic column combined with UHPLC-MS/MS for the determination of ligustrazine has been developed in rat serum. Relevant experimental parameters, such as $\mathrm{pH}$ of loading solution, loading volume, and desorption condition, were evaluated. Finally, the applicability of the method was further confirmed by the determination of ligustrazine in rat serum after dosing of ligustrazine tablets to rats.

\section{EXPERIMENTAL}

\section{Reagents and chemicals}

Methanol, acetonitrile and formic acid of chromatographic grade were supplied from Sigma-Aldrich (Shanghai, China). Sodium hydroxide and disodium hydrogen phosphate of analytical grade were brought from Sinopharm group (Shanghai, China). Ligustrazine phosphate tablets (Lot 111119) were obtained from Livzon Pharmaceutical Group (Shaoguan, China), and ligustrazine standard (98\%) was purchased from Sigma-Aldrich (Shanghai, China). Caffeine (99\%, IS) was supplied from Pureone biotechnology (Shanghai, China), and the chemical structure of ligustrazine and caffeine were shown in Fig. 1. Purified water was

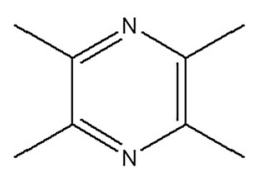

(A)

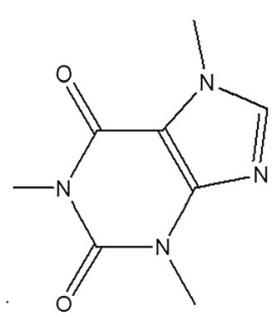

(B)
Fig. 1. Chemical structure of analytes. A. ligustrazine, B. caffeine (IS) obtained by Millipore water purification apparatus (Bedford, USA). Poly (MAA-EGDMA) extraction material was synthesized and assembled in accordance with previous work [25]. The monolithic system is modified from a conventional plastic syringe $(1 \mathrm{~mL})$, namely a metal needle of the syringe is replaced with a monolithic capillary $(3 \mathrm{~cm} \times 530 \mu \mathrm{m}$, id), using adhesive for better attachment, which can be used for PMME. A TS2-60 syringe pump was supplied from Lange Company (Baoding, China), which was used transport the solution throughout the extraction step.

A ligustrazine stock solution of $5.0 \mu \mathrm{g} \mathrm{mL}^{-1}$ was prepared with methanol, and the IS solution of $0.5 \mu \mathrm{g} \mathrm{mL}^{-1}$ was obtained in the same way. Working solutions containing a certain concentration were gained daily by diluted with phosphate buffer solution ( $\mathrm{pH}$ 5.0). Several ligustrazine phosphate tablets were ground by a gator and prepared as a suspension $\left(4 \mathrm{mg} \mathrm{mL}^{-1}\right)$ with water. A dose of ligustrazine $\left(20 \mu \mathrm{g} \mathrm{g}^{-1}\right)$ was proposed according to the rat and human equivalent dose conversion method [26]. All the prepared solutions were kept at $4{ }^{\circ} \mathrm{C}$ in dark.

\section{Instrument and chromatographic conditions}

UHPLC-MS/MS analysis system includes a Shimadzu LC30A (Tokyo, Japan) and an AB Sciex-4500 (Foster City, USA). A Velox column $(2.7 \mu \mathrm{m}, 100 \mathrm{~mm} \times 4.6)$ form Shimadzu (Japan) was used and kept at $40{ }^{\circ} \mathrm{C}$, and the flow rate was set at $0.3 \mathrm{~mL} \mathrm{~min}^{-1}$. The system was initially equilibrated with water and methanol $(95: 5, v / v)$ including $0.1 \%$ formic acid, then the content of methanol was increased from 5 to $80 \%$ within $5 \mathrm{~min}$, maintained at this for another $3 \mathrm{~min}$, and reduced linearly back to $5 \%$ methanol in following $0.1 \mathrm{~min}$ and re-equilibrated for another $2 \mathrm{~min}$.

Nitrogen $\left(\mathrm{N}_{2}\right)$ was used as curtain gas and collision gas. The qualification and quantification ion pairs and the optimized collision energies and cone voltages of ligustrazine and IS compound were shown in Table 1. MultiQuant software (version 3.0.2) and Analyst software (Version 1.6.3) were used for the UHPLC-MS/MS operation and data processing, respectively.

\section{Degradation study of ligustrazine in rat serum after oral administration}

Twenty-seven Wistar rats weighing $(200 \pm 10)$ g, cleangrade and male, were taken from Center of Laboratorial Animals, Hubei University of Chinese Medicine (China). The experimental program was licensed by Ethics Committee of Experimental Animals, Hubei University of Chinese Medicine. The rats were unrestrained to eat and drink at a constant temperature $\left(25 \pm 2{ }^{\circ} \mathrm{C}\right)$ and humidity $(60 \pm$ $5 \%$ ), and retained a $12 \mathrm{~h}$ light/dark cycle in the course of experiments.

Subsequently, the experimental rats were fed once with $1.0 \mathrm{~mL}$ of ligustrazine suspension by gastric gavage. Then they were sacrificed by cervical dislocation after $0,0.5,1,1.5$, $2,3,4,5 \mathrm{~h}$, respectively. At the same time, three rats were irrigated with an equal volume of water without ligustrazine drug as control samples. 
Table 1. Mass spectrometry conditions of analytes

\begin{tabular}{|c|c|c|c|c|c|c|c|}
\hline Target compound & Retention time (min) & Molecular formula & MW & Parent ion & Daughter ion & DP (V) & $\begin{array}{l}\mathrm{CE} \\
\text { (V) }\end{array}$ \\
\hline \multirow[t]{3}{*}{ Ligustrazine } & \multirow[t]{3}{*}{4.75} & \multirow[t]{3}{*}{$\mathrm{C}_{8} \mathrm{H}_{12} \mathrm{~N}_{2}$} & \multirow[t]{3}{*}{136.19} & \multirow[t]{3}{*}{137.2} & $55.1^{\mathrm{a}}$ & 80 & 30 \\
\hline & & & & & 80.1 & 90 & 37 \\
\hline & & & & & 121.0 & 80 & 37 \\
\hline \multirow[t]{3}{*}{ Caffeine } & \multirow[t]{3}{*}{4.46} & \multirow[t]{3}{*}{$\mathrm{C}_{8} \mathrm{H}_{10} \mathrm{~N}_{4} \mathrm{O}_{2}$} & \multirow[t]{3}{*}{194.19} & \multirow[t]{3}{*}{195.2} & $138.1^{\mathrm{a}}$ & 70 & 26 \\
\hline & & & & & 110.2 & 80 & 31 \\
\hline & & & & & 123.0 & 80 & 40 \\
\hline
\end{tabular}

${ }^{a}$ Quantitative ion.

\section{Sample preparation}

The collected blood samples (about $4.0 \mathrm{~mL}$ ) were stand for $30 \mathrm{~min}$, and then centrifuged at $5,000 \mathrm{rmp}$ for $5 \mathrm{~min}$. Pipetted $0.5 \mathrm{~mL}$ of the supernatant and mixed with $50 \mu \mathrm{L}$ IS solution, then added $4.5 \mathrm{~mL}$ of trichloroacetic acid solution (60 $\mathrm{mmol} \mathrm{L}^{-1}$ ) to precipitate proteins, subsequently the solution was centrifugated under $15,000 \mathrm{r} \mathrm{min}^{-1}$ for $10 \mathrm{~min}$. Finally, pipetted $1.0 \mathrm{~mL}$ of the collecting supernatant, and diluted 10 times with the phosphate solution, then passed through a $0.22 \mu \mathrm{m}$ filter membrane before the PMME procedure.

The PMME procedure included column conditioning, extraction, washing, and desorption steps. Firstly, column conditioning step was performed by methanol and phosphate solution (20 mmol L ${ }^{-1}, \mathrm{pH}$ 5.0) in sequence. Secondly, the sample solution was loading at the velocity of $0.15 \mathrm{~mL}$ $\min ^{-1}$, and $0.2 \mathrm{~mL}$ of fore-mentioned phosphate solution and $0.2 \mathrm{~mL}$ of water were driven through the extraction column in order to eliminate the residual matrices. Then the remaining water within the column was drained using a dry syringe before the desorption step. Finally, a solution containing $0.1 \%$ acetic acid and methanol $(10: 90, v / v)$ was used to elute ligustrazine from capillary for subsequent UHPLC-MS/MS analysis.

\section{Method validation}

To validate the proposed method, several experiments including matrix effect, linearity, limit of detection (LOD), limit of quantification (LOQ), trueness, precision, and stability were performed under optimal extraction conditions. In current study, matrix effect was measured by contrasting response intensity of samples extracts with equivalent amount of the ligustrazine added to pure solutions prepared in mobile phase. The difference in response between the two divided by the pure solution response determines the degree of matrix effect of the ligustrazine in matrix samples. The linearity of the method was acquired by plotting peak area ratios (ligustrazine/IS) versus concentration ratios (ligustrazine/IS) after injecting series of standard solutions in the range of $2-2,000 \mathrm{ng} \mathrm{mL}^{-1}$ in triplicate. LOD and LOQ were calculated based on the signal-to-noise of 3 and 10. The trueness and precision was expressed by recoveries and relative standard deviations (RSDs) measured at six replicate experiments in a day and successive three days, respectively. The stabilities of ligustrazine in rat serum were investigated under different storage condition including $25^{\circ} \mathrm{C}$ for $8 \mathrm{~h}, 3$ times of freeze/thaw trials and post-preparation for $24 \mathrm{~h}$.

\section{RESULTS AND DISCUSSION}

\section{Chromatographic analysis}

To obtain satisfactory qualitative and quantitative analysis, a new UHPLC-MS/MS method was established for ligustrazine in rat serum extracts. Several various mobile phases were investigated to achieve the optimal chromatographic separation. The results showed that the mobile phase with water and methanol (both containing $0.1 \%$ formic acid) were suitable for providing stable baseline and symmetrical peaks for ligustazine and IS compounds. The optimization of daughter ions as well as their collision energies and cone voltages was carried out under the daughter scan mode to establish the Multiple Reaction Monitoring (MRM) method for quantification and confirmation. The most abundant product ions were selected for quantification and the second intense one for qualification. The relative parameters were listed in Table 1.

\section{Optimization of PMME}

Several experimental conditions affecting the extraction efficiency are investigated, for example, $\mathrm{pH}$ of the sample solution, content of organic phase in loading solution, extraction capacity, washing solution, desorption solution, and flow rate, etc. The optimization was carried out in a ligustrazine working solution of $0.05 \mu \mathrm{g} \mathrm{mL}^{-1}$ diluted with phosphate solution (20 $\mathrm{mmol} \mathrm{L}{ }^{-1}$ ). Each experiment was repeated three times.

Effect of $\boldsymbol{p H}$. To study the $\mathrm{pH}$ on extraction efficiency, the $\mathrm{pH}$ of extraction solution was adjusted to 3.0-7.0. Fig. 2 showed that the extraction efficiency reached the peak at $\mathrm{pH}$ 5.0 , which was caused mainly by electrostatic attraction between the cationic target compound and the carboxylate anion within extraction material. When $\mathrm{pH}$ was increasing from 3 to 5, carboxylic groups within poly (MAA-coEGDMA) were gradually ionized, which resulted in increasing retention of anlayte. However, when $\mathrm{pH}$ was further increased above 5.0, the ligustrazine molecule was gradually transformed to its neutral state in view of its $\mathrm{pKa}$ values of 3.2, which resulted in weakened ion exchange interaction. Thus, adjust the $\mathrm{pH}$ of the sample solution to 5.0 in subsequent experiments. 


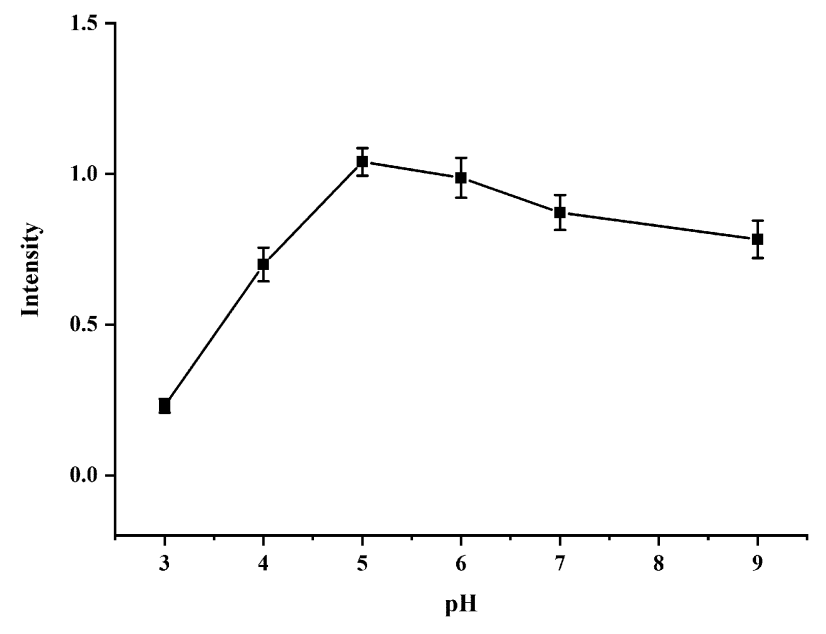

Fig. 2. Effect of $\mathrm{pH}$ in the sample solutions

Effect of organic solvent content in loading solution. The effect of organic solvent was investigated by adding 0-40\% of acetonitrile to the sample solution. Fig. 3 showed that extraction efficiency slightly increased firstly and then rapidly declined with the increasing content of acetonitrile in sample solution. This might be due to swell of monolith column with the addition of acetonitrile, thus hydrophobic interaction sites within the polymer skeleton were more easily exposed to target analyte, which could increase the retention of target analytes. Meanwhile, the hydrophobic interaction between analyte and the polymer skeleton would decrease with increasing organic content in loading solution. This phenomenon was also confirmed in the previous study on polymer monolithic column [20].

Whereas both factors worked on the extraction efficiency of analyte, the existence of acetonitrile could increase the retention of analyte on the extraction material, while the addition of extra acetonitrile resulted in low extraction efficiency. This phenomenon also fully proved the hydrophobic interaction as one of the extraction mechanisms. To

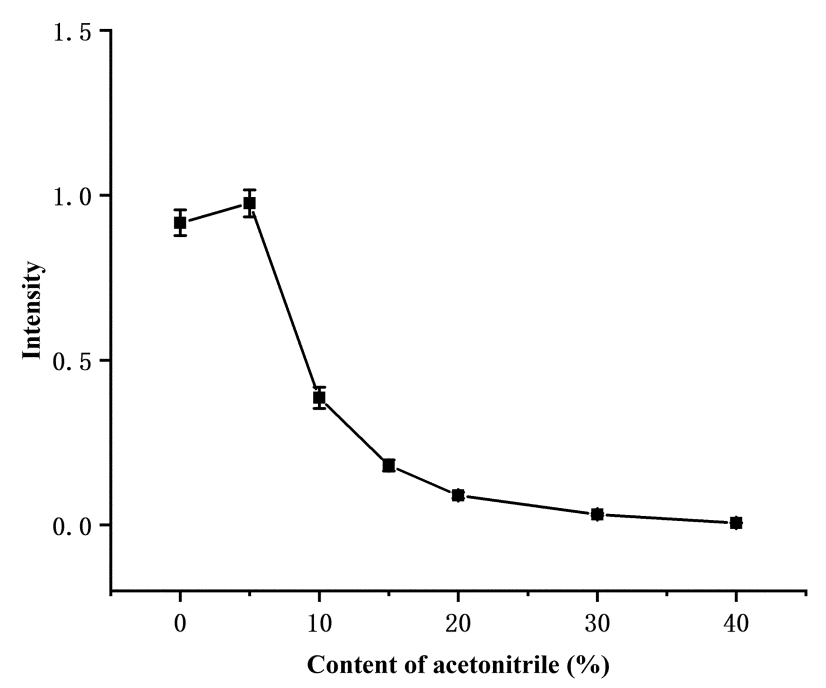

Fig. 3. Effect of acetonitrile content in the sample solutions

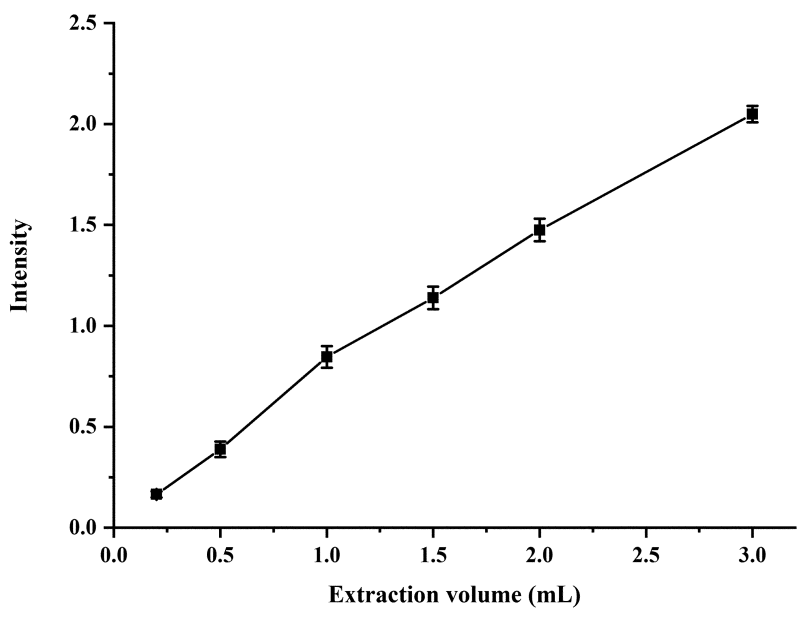

Fig. 4. Extraction capacity for PMME

Table 2. The recoveries and RSDs at three different concentrations of ligustrazine in serum samples by PMME/UPLC-MS-MS

\begin{tabular}{lrrrr}
\hline \multirow{4}{*}{ Analyte } & \multicolumn{2}{c}{$\begin{array}{c}\text { Concentration } \\
\left(\mathrm{ng} \mathrm{mL}^{-1}\right)\end{array}$} & RSD (\%) & $\begin{array}{c}\text { Accuracy } \\
(\%)\end{array}$ \\
\cline { 2 - 3 } Ligustrazine & Added & Founded & \multicolumn{4}{c}{ Intra-day $(n=6)$} \\
& 50 & 43.9 & 8.3 & 87.8 \\
& 200 & 184.8 & 6.5 & 92.4 \\
& 1,000 & 945.0 & 3.6 & 94.5 \\
& 50 & 41.3 & 9.7 & 82.6 \\
& 200 & 183.6 & 7.5 & 91.8 \\
& 1,000 & 953.0 & 6.8 & 95.3 \\
\hline
\end{tabular}

obtain good extraction efficiency for ligustrazine and ensure high stability of extraction column, no organic solvent was added in loading solution.

Investigation of extraction capacity. The extraction capacity of the monolithic column to ligustrazine was conducted by plotting between the extracted amounts and loading volume. Fig. 4 showed that the extracted amount increased linearly with the increase of sample volume, even when the extraction volume reached $3.0 \mathrm{~mL}$, the extraction equilibrium was not yet reached, which illustrated that the monolithic column has a strong enrichment capacity for ligustrazine. Considering the sensitivity and rapidity of the proposed method, only $1.0 \mathrm{~mL}$ of sample solution was adequate.

Optimization of the washing and desorption steps. To prevent the matrix from polluting analytical column, and reduce interference during the course of detection, a washing step was necessary after the sample loading. The phosphate solution mentioned above was employed to remove impurities and weakly adsorbed compounds. Since the presence of salt would inhibit the signal of MS detection, it was very necessary to use an equal volume of water to eliminate remanent salt. 
Table 3. Comparison between different methods to determine ligustrazine

\begin{tabular}{|c|c|c|c|c|c|c|c|c|c|c|c|}
\hline Residues & Matrix & $\begin{array}{l}\text { Sample } \\
\text { volume/ } \\
\text { mass }\end{array}$ & $\begin{array}{c}\text { Extraction } \\
\text { volume }(\mu \mathrm{L})\end{array}$ & $\begin{array}{l}\text { Extraction } \\
\text { solvents }\end{array}$ & Clean-up & Determination & $\begin{array}{l}\text { LOD (ng } \\
\left.\mathrm{mL}^{-1}\right)\end{array}$ & $\begin{array}{l}\text { LOQ (ng } \\
\left.\mathrm{mL}^{-1}\right)\end{array}$ & $\begin{array}{l}\text { Recoveries } \\
(\%)\end{array}$ & $\begin{array}{c}\text { RSDs } \\
(\%)\end{array}$ & Ref \\
\hline tetramethylpyrazine & $\begin{array}{l}\text { Rat brain and } \\
\text { blood }\end{array}$ & $30 \mu \mathrm{L}$ & - & $\begin{array}{l}\text { In vivo } \\
\text { microdialysis }\end{array}$ & - & LC-MS & - & 0.991 & $94.6-99.1$ & $\begin{array}{c}1.4- \\
6.3\end{array}$ & {$[15]$} \\
\hline Ligustrazine & $\begin{array}{c}\text { Methanol } \\
\text { solution (80\%) }\end{array}$ & $1 \mathrm{~g}$ & $10 \mathrm{~mL}$ & Methanol & - & $\begin{array}{l}\text { Electrochemical } \\
\text { Sensor }\end{array}$ & $0.1 \mu \mathrm{M}$ & - & $99.2-101.3$ & $\begin{array}{c}1.8- \\
3.6\end{array}$ & {$[13]$} \\
\hline Ligustrazine & Rat plasma & $100 \mu \mathrm{L}$ & $200 \mu \mathrm{L}$ & $\begin{array}{c}\text { Acetonitrile: } \\
\text { methanol }(1: 1, v / \\
v)\end{array}$ & $\begin{array}{l}\text { Automated on-line } \\
\text { SPE }\end{array}$ & LC-MS/MS & 0.20 & - & $90.5-90.8$ & $\begin{array}{c}7.6- \\
9.6\end{array}$ & {$[16]$} \\
\hline Ligustrazine & Rhizome & $0.5 \mathrm{~g}$ & $25 \mathrm{~mL}$ & Methanol & - & LC-UV & 44 & 133 & $84.9-88.6$ & $\begin{array}{c}0.01- \\
1.1\end{array}$ & [9] \\
\hline Ligustrazine & $\begin{array}{l}\text { Si-Wu-Tang } \\
\text { (herbs), }\end{array}$ & $200 \mathrm{mg}$ & $20 \mathrm{~mL}$ & $\begin{array}{l}70 \%(v / v) \\
\text { methanol }\end{array}$ & - & LC-MS & 5 & 20 & $86.5-94.6$ & $\begin{array}{l}2.2- \\
10.9\end{array}$ & {$[18]$} \\
\hline tetramethylpyrazine & Dog plasm & $500 \mu \mathrm{L}$ & $1.2 \mathrm{~mL}$ & Methanol & Protein precipitation & LC-MS & - & 20 & $90.5-108.0$ & $\begin{array}{c}4.9- \\
7.4\end{array}$ & {$[10]$} \\
\hline $\begin{array}{l}\text { Ligustrazine } \\
\text { hydrochloride }\end{array}$ & $\begin{array}{c}\text { Plasma and } \\
\text { brain dialysate }\end{array}$ & $500 \mu \mathrm{L}$ & - & - & SPE & LC-MS/MS & 0.02 & 0.05 & $96.0-97.4$ & $\begin{array}{c}2.6- \\
4.2\end{array}$ & {$[17]$} \\
\hline Ligustrazine & Rat serum & $500 \mu L$ & $10 \mathrm{~mL}$ & $\begin{array}{c}\text { Phosphate buffer } \\
\text { solution }\end{array}$ & $\begin{array}{c}P M M E(\text { poly }(M A A- \\
\text { co-EGDMA) } \\
\text { monolithic column) }\end{array}$ & $U P L C-M S / M S$ & 0.14 & 0.47 & $82.6-95.3$ & $\begin{array}{c}3.6- \\
9.7\end{array}$ & $\begin{array}{l}\text { This } \\
\text { work }\end{array}$ \\
\hline
\end{tabular}




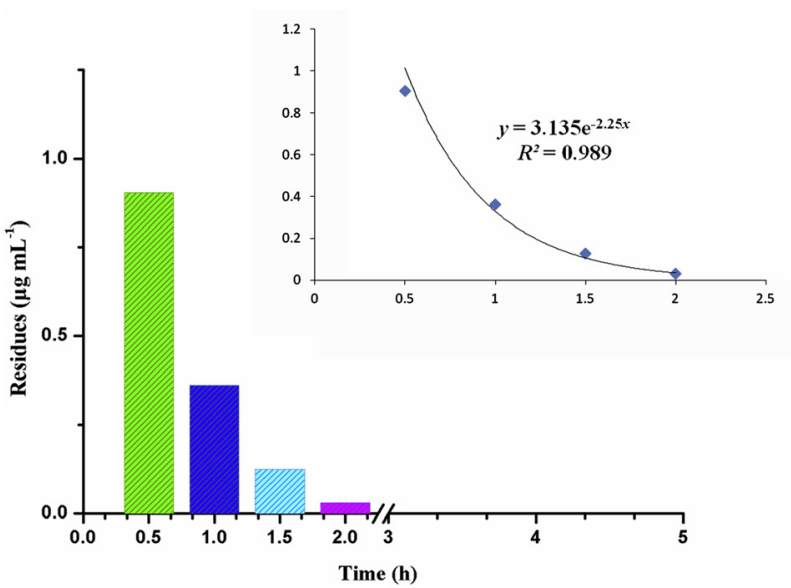

Fig. 5. Degradation curve of ligustrazine in rat serum after oral administration $\left(20 \mu \mathrm{g} \mathrm{g}^{-1}\right.$ body weight)

Desorption solution was also investigated in order to recover completely from the extraction column. The results showed that the $0.1 \mathrm{~mL}$ solution including water and methanol $(10: 90, v / v)$ could elute completely all the analyte from the monolith column, which could be injected into the liquid chromatography without any reconstituted step.

Effect of flow rate. The influence of loading flow rate was evaluated from 0.05 to $0.20 \mathrm{~mL} \mathrm{~min}{ }^{-1}$ at $0.05 \mathrm{~mL} \mathrm{~min}^{-1}$ intervals. We found that increasing flow rate could shorten the extraction time but increase the column pressure although there was no change in extraction efficiency, while excessive pressure might cause damage to the device. Considering both factors fore-mentioned, $0.15 \mathrm{~mL} \mathrm{~min}{ }^{-1}$ was suitable for the loading flow rate. As for flow rate of the desorption step, considering the small volume of the desorption solution, $0.05 \mathrm{~mL} \mathrm{~min}^{-1}$ was selected to maintain the stability in the course of solution collection.

\section{METHOD VALIDATION}

\section{Calibration curves and detection limit}

Matrix effects could not be avoided when we performed a HPLC-MS-ESI analysis, due to the matrix interference in the real sample solution [27]. The result showed that the matrix effects of ligustrazine ranged from -16.2 to $5.9 \%$ at three spiked concentrations of 10,100 , and $1,000 \mathrm{ng} \mathrm{mL} \mathrm{m}^{-1}$, indicating the matrix of the extract might cause interference during the determination. Consequently, matrix-matched calibration curve was utilized to obtain true results throughout this study.

Good linearity ranging from 2 to $2,000 \mathrm{ng} \mathrm{mL} \mathrm{m}^{-1}$ was acquired by plotting between area ratio and concentration ratio of ligustrazine/IS. The regression equation for ligustrazine in rat serum was $y=0.08625 x+0.10788\left(R^{2}\right.$ $=0.9987)$. The LOD and LOQ of the proposed method were also calculated to be 0.14 and $0.47 \mathrm{ng} \mathrm{mL} L^{-1}$ in rat serum.

\section{Trueness and precision}

The serum sample solutions were prepared by spiked with ligustrazine at three concentrations of 50,200, and 1,000 ng $\mathrm{mL}^{-1}$. The results was shown in Table 2 that excellent precision was found with RSDs less than $8.3 \%$ for intra-day and $9.7 \%$ for inter-day, respectively. The recoveries were between 82.6 and $95.3 \%$, and RSDs were less than $9.7 \%$ for serum samples, indicating the developed method was reliable for routine monitoring of real rat serum samples.

\section{Stability}

The RSD of the mean measurement values was within 3.8\% in all stability tests for ligustrazine in serum. No change was observed for serum samples kept at 25 for $8 \mathrm{~h}$ or postpreparation for $24 \mathrm{~h}$. Three times of freeze/thaw trials for the samples have also no different on the analytical results for the ligustrazine.

\section{Method comparison}

The performance of the developed method for the determination of ligustrazine was also compared with previous literatures listed in Table 3. Lower LOD and less solvent consumption of the proposed method were identified than most of them, which would be complementary with those routine methods. Moreover, the current extraction process was economical and environmentally friendly, and could meet the requirements of green chemistry. Compared with traditional coated capillaries, the monolithic column provided a larger specific surface area and possessed tremendous loading capability obtained from the condition experiment. Therefore, it would be helpful for enhancing the extraction efficiency. Furthermore, the good permeability of the extraction material could be quickly extracted, which was very attractive for high-throughput analysis of multiple samples.

\section{Application to serum of ligustrazine-treated rats}

The proposed method was subsequently used to continuous monitoring of serum samples from rats dosed with ligustrazine tablets to further validate the practicability. The degradation curve of ligustrazine in rat serum after oral drug administration of $20 \mu \mathrm{g} \mathrm{g}^{-1}$ body weight was shown in Fig. 5. Ligustrazine could not be detected in serum at control sample and 0 hour after oral administration of ligustrazine tablets to rats, while ligustrazine was detected in serum after $0.5 \mathrm{~h}$. Thereafter, the concentration of ligustrazine decreased rapidly, and reached a low lever after $2 \mathrm{~h}$ and could not be detected in subsequent time. The degradation curve equation was $y=3.135 e^{-2.25 x}$ with $r^{2}$ of 0.9900 , and the half-time for ligustrazine in rat serum was calculated to be 0.308 hour according to Origin 8.0 software (OriginLab, MA, USA). The result was very close to the pharmacokinetic study of Nie's group [7]. The characteristic chromatograms of blank plasma before and after adding the reference standard compounds, and plasma obtained after the oral administration of ligustrazine are shown in Fig. 6. 
A
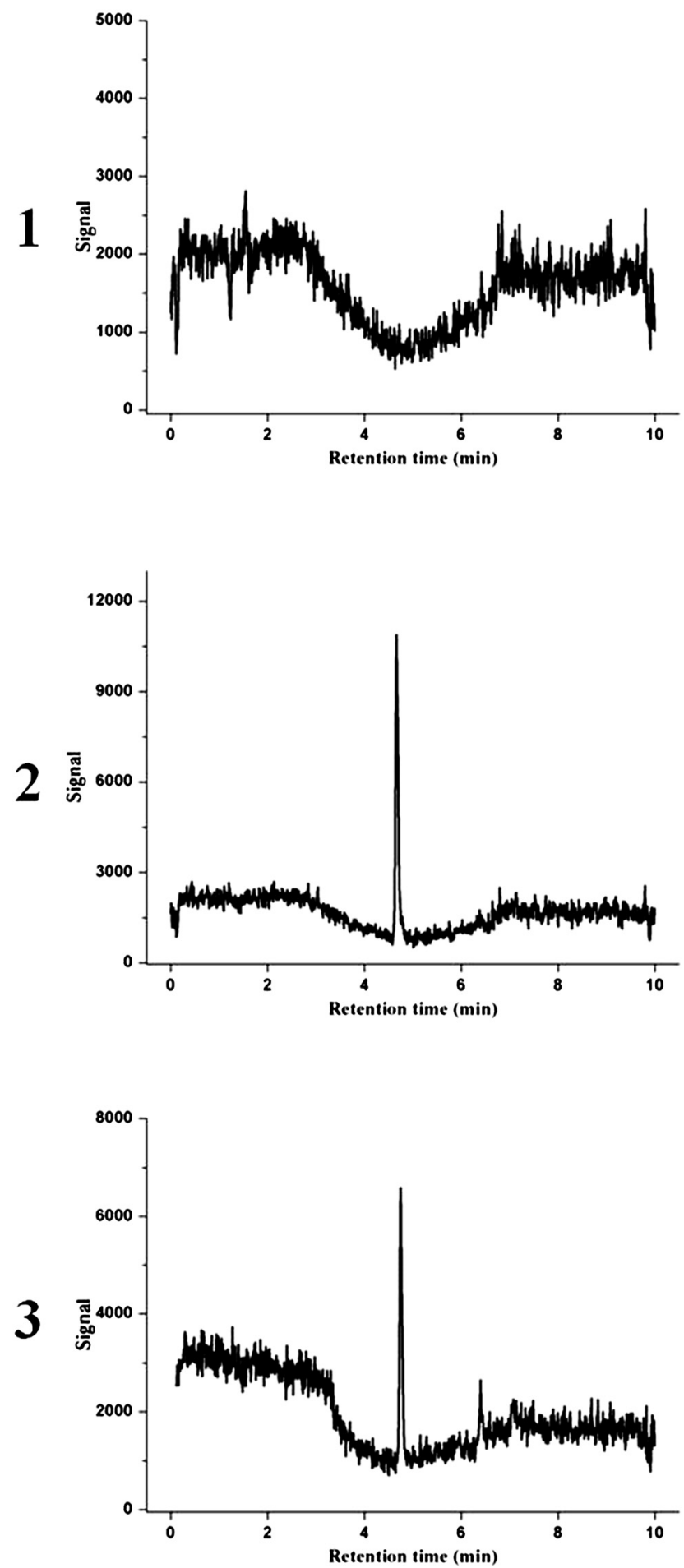

B
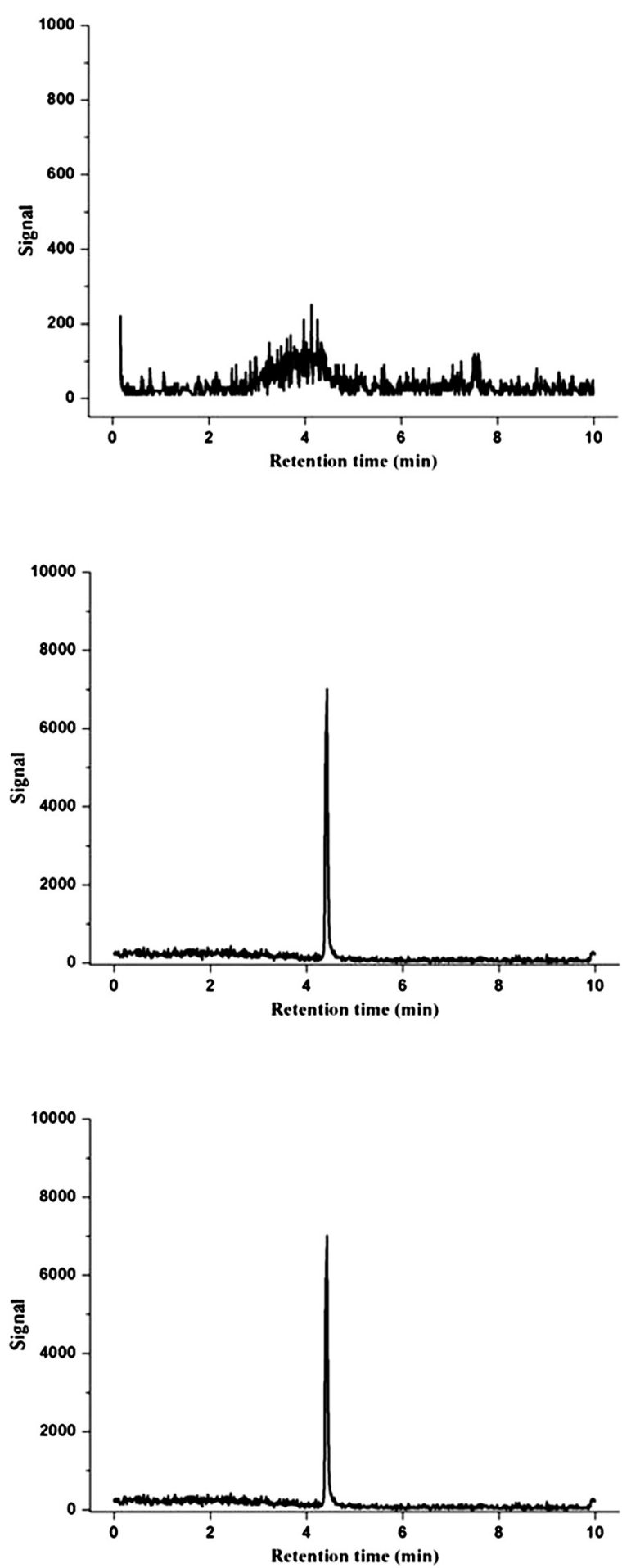

Fig. 6. MRM chromatograms of ligustrazine (A) and caffeine (IS) (B): 1. blank serum; 2. blank serum spiked with ligustrazine and IS; 3. serum sample at $0.5 \mathrm{~h}$ after oral administration of ligustrazine $\left(20 \mu \mathrm{g} \mathrm{g}^{-1}\right.$ body weight $)$

\section{CONCLUSION}

In current research, an effective analytical method for the determination of ligustrazine in rat serum was established. The extraction was carried out by using PMME technology followed by UHPLC-MS/MS analysis, and that was economical and environmentally friendly, which would be complementary with routine methods. In addition, the proposed method revealed good analytical characteristics, including low LOD 
(0.14 $\left.\mathrm{ng} \mathrm{mL}^{-1}\right)$, trueness (82.6-95.3\%), precision ( $\left.\leq 9.7 \%\right)$, and stability $(\leq 3.8 \%)$, Furthermore, the present method was available in routine monitoring or pharmacokinetic study of ligustrazine drug in rat serum, which also provided a potential for the determination of ligustrazine in other biologic matrices.

\section{FUNDING}

The study was funded by Hubei Innovation Center of Agricultural Science and Technology of China (2019-620000-001-26).

\section{ACKNOWLEDGEMENTS}

The authors would like to thank Professor Yuqi Feng (Department of Chemistry, Wuhan University, China) for the help on the synthesis of extraction material.

\section{ABBREVIATIONS}

$\begin{array}{ll}\text { POLY (MAA-EGDMA) } & \begin{array}{l}\text { poly (methacrylic acid- } \\ \text { ethylene glycol dimethacrylate) }\end{array} \\ \text { PMME } & \text { polymer monolith micro-extraction } \\ \text { LLE } & \text { liquid-liquid extraction } \\ \text { SPE } & \text { solid phase extraction } \\ \text { RSDs } & \text { relative standard deviation } \\ \text { IS } & \text { internal standard }\end{array}$

\section{REFERENCES}

1. Xiao, M.; Qian, C. Y.; Luo, X.; Yang, M. B.; Zhang, Y. F.; Wu, C. Y.; Mok, C.; Lee, P.; Zuo, Z. J. Ethnopharmacol. 2019, 235, 100-10.

2. Chen, Z. J.; Zhang, C.; Gao, F.; Fu, Q.; Fu, C. M.; He, Y.; Zhang, J. M. Food Chem.Toxicol. 2018, 119, 309-25.

3. Lei, X. Q.; Li, G.; Cheng, L.; Wang, X. L.; Meng, F. Y. J. Pharm. Biomed. Anal. 2018, 154, 123-37.

4. Zhang, L. Y.; Zhang, W.; Chen, W. L.; Chen, G.,. J. Pharm. Biomed. Anal. 2016, 131, 107-12.
5. He, Y. F.; Li, Q.; Bi, K. S. J. Sep.Sci. 2015, 38 (7), 1090-9.

6. Wang, H.; Bao, Q.; Yi, H.; Xia, Q. J. Ethnopharmacol. 2019, 239, 111895.

7. Wang, Q.; Sun, H.; Yu, L.; Ma, X.; Jiang, B.; Bi, C.; Wang, Z.; Fan, Q.; Yu, Y.; Liu, Y.; Nie, H. Naunyn Schmiedeberg's Arch. Pharmacol. 2019, 392 (5), 565-72.

8. Li, S. Q.; Yi, X. T.; Li, L. F.; Wu, H. N. World J. Biochem. Mol. Biol. 2018, 3 (1), 16-21.

9. Liu, J. L.; Zheng, S. L.; Fan, Q. J.; Yuan, J. C.; Yang, S. M.; Kong, F. L., Asian J. Chem. 2014, 26 (16), 5026-8.

10. Li, L. L.; Zhang, Z. R.; Gong, T.; He, L. L.; Deng, L. J. Pharm. Biomed. Anal. 2006, 41 (4), 1083-7.

11. Lv, K.; Li, H.; Ding, M. J. Chromatogr. A 2000, 878 (1), 147-52.

12. Li, Y.; Li, Y. F.; Wang, L.; Zou, L. N.; Ye, B. X. Anal. Method 2016, 8 (10), 2144-9.

13. Yan, S.; Yue, Y. Z.; Yang, L. L.; Bian, Y. Y.; Yue, J.; Zeng, L. Int. J. Electrochem. Sci. 2017, 12 (9), 8495-503.

14. Li, H. L.; Wang, B. J.; Yuan, G. Y.; Guo, R. C. Int. J. Clin. Pharmacol. Ther. 2018, 56 (8), 387-92.

15. Liao, W. G.; Huang, X. J.; Yin, Y. X.; Liu, B.; Zhu, R. Z. Biomed. Chromatogr. 2018, 32 (6), 11.

16. Zeng, M. F.; Zhang, J.; Yang, Y. F.; Jin, Y.; Xiao, W.; Wang, Z. Z.; Ding, G.; Yan, R. J. J. Pharm. Biomed. Anal. 2014, 88, 354-63.

17. Lv, Y. F.; Hu, X.; Cheng, W. M.; Nie, Y. L.; Bi, K. S. Chromatographia 2008, 68 (1-2), 105-10.

18. Wang, Z. J.; Wo, S. K.; Wang, L.; Lau, C. B. S.; Lee, V. H. L.; Chow, M. S. S.; Zuo, Z. J. Pharm. Biomed. Anal. 2009, 50 (2), 232-44.

19. Wang, P.; Jin, X.; Qi, M.; Fang, L. J. Chromatogr. B 2004, (813), 263-8.

20. Fan, Y.; Feng, Y. Q.; Da, S. L.; Shi, Z. G. Anal. Chim. Acta 2004, 523 (2), 251-8.

21. Ali, I.; Gupta, V. K.; Aboul-Enein, H. Y.; Hussain, A. J. Sep. Sci. 2008, 31 (11), 2040-53.

22. Fang, W. L.; Xia, L. J.; Huang, X.; Guo, X. F.; Ding, J.; Wang, H.; Feng, Y. Q. Chromatographia 2018, 81 (10), 1381-9.

23. Wang, R.; Li, W. Q.; Chen, Z. L. Anal. Chim. Acta 2018, 1018, 111-8.

24. Zhang, J.; Chen, B. B.; Wang, H.; He, M.; Hu, B. Anal. Chem. 2017, 89 (12), 6878-85.

25. Hu, X. Z.; Wang, J. X.; Feng, Y. Q. J. Agric. Food Chem. 2010, 58 (1), 112-9.

26. Nair, A. B.; Jacob, S. J. Basic Clin. Pharm. 2016, 7 (2), 27-31.

27. Taylor, P. J. Clin. Biochem. 2005, 38 (4), 328-34. 